\title{
On Beauty ... and the History of Business
}

\section{KATHY PEISS}

Beauty and business seem opposite terms but in fact have had an important and consequential relationship that business historians are only now exploring. This paper sketches several major themes and approaches to the topic. The first is the emergence of a large sector of the economy devoted to selling beauty aids, fashions, bodily care, and style to American women and men. Another is the deployment of beauty as a business strategy-in creating brands, sales, and marketing; in managing the workplace; and in projecting corporate identities. A third considers the sale of beauty itself, as a value added and attached to a wide range of goods, from art to bodies. These broad approaches suggest new directions for future research.

What can business historians learn by making beauty a subject of research and investigation? Beauty and business: one might as well say beauty and the beast. These terms conjure up distinct domains, different images, and contrasting values. Beauty is seemingly frivolous, superficial, and female, the subject of aesthetics, art, poetry, and, most recently, feminist criticism. Business, in contrast, connotes serious, consequential —indeed, manly — activity, the intellectual domain of economists and social scientists.

Until recently, business historians have not yielded to beautyat least as a subject of scholarly inquiry. The field has been so much

Enterprise $\&$ Society 1 (Sept. 2000): 485-506. @ 2000 by the author. All rights reserved.

KATHY PEISS is professor of history at the University of Massachusetts, Amherst. Contact information: Department of History, Herter Hall, Box 33930, University of Massachusetts, Amherst, MA 01003-3930, USA < peiss@history. umass.edu>

I thank Sally Clarke and Peter Agree for their comments on an earlier version of this essay; discussions with Philip Scranton, Roger Horowitz, Will Hausman, and the participants of the Hagley Conference on Beauty and Business (March 1999) aided my thinking on this subject. 
defined by studies of heavy industry and corporate power that the activities of hairdressers, fashion designers, and "Avon Ladies" have largely gone unnoticed. But beauty is big business, with large-scale production, international distribution networks, media-saturation advertising, scientific marketing, and sales in the billions of dollars. And business historians have begun to take notice. Placing business within the broad narratives of American history, they increasingly investigate how economic enterprises interacted with cultural and social developments, responding to and influencing them in turn. They have opened new directions for research on gender, race, the creation of markets, and the role of consumers. Interest in beauty, style, and fashion is a logical development in the new business history. ${ }^{1}$

And what of those who write about beauty? They pay much more attention to the power of representation-paintings, poems, prescriptive literature, and advertising images - than to the strategies of business. Critics of the commercialization of beauty tend to treat business as a monolith, an industry whose motives are uniform, actions synchronized, and effects transparent. ${ }^{2}$ The papers in this special issue of Enterprise $\&$ Society go beyond such approaches to investigate closely the relationship between beauty and business practices. They explore the assumptions and decision making of entrepreneurs, manufacturers, retailers, advertisers, and consumers. They consider how changing ideals of beauty, notions of fashion, and attitudes about the body shaped business strategies. Just as important, they show how businesses profited from their attention to beauty and influenced cultural ideals and social identities embodied in faces, figures, and fashion. These case studies demonstrate that beauty and business are worth pondering further.

A broad look at the historical relationship between beauty and business points to several key approaches to this subject. One concerns the emergence of a large sector of the economy devoted to selling beauty aids, fashions, bodily care, and style to American women, and, increasingly, to men. Another is the deployment of beauty as a business strategy - in creating brands, sales, and marketing; in managing the workplace; and in projecting corporate identities. A third considers the sale of beauty itself, as a value added and attached to a

1. Kenneth Lipartito, "Culture and the Practice of Business History," Business and Economic History 24 (Winter 1995): 1-41; "The Future of Business History" special issue, ibid. 26 (Fall 1997); "Gender and Business History" symposium, Business History Review 72 (Summer 1998): 185-249.

2. See, for example, Susan Bordo, Unbearable Weight: Feminism, Western Culture, and the Body (Berkeley, Calif., 1993); Dean MacCannell and Juliet Flower MacCannell, "The Beauty System," in The Ideology of Conduct, ed. Nancy Armstrong and Leonard Tennenhouse (New York, 1987), 206-38. For a popular version, see Naomi Wolf, The Beauty Myth (New York, 1991). 
wide range of goods, from art to bodies. These approaches offer new directions for future research.

\section{A Short Disquisition on Beauty}

The word 'beauty' requires a closer look at the longstanding intellectual and cultural traditions that have defined its meaning. Beauty is an aesthetic category, applied to art and objects, faces and bodies, nature and souls. In the Western tradition of aesthetics, at least since the eighteenth century, beauty has been understood as a quality apart, dissociated from history and social contingencies. For philosophers, poets, and artists, the aesthetic was an autonomous and transcendent realm outside the ordinary, the mundane, and the utilitarian. The contemplation of beauty - whether the sublimity of Niagara Falls, the sensuousness of a Rubens painting, or the charm of a young girl's face - took one out of the self, into a higher realm of appreciation and discernment. Large quantities of ink were spilled in the nineteenth century in the effort to identify those qualities of female beauty upon which everyone could agree. There were "celestial” beauties - often tubercular or close to death-and robust pulchritude, classical Venuses and Oriental exotics, blondes and brunettes, all placed in a moral order and physical hierarchy based on complexion, hair, and symmetry of face and form. ${ }^{3}$

This aesthetic tradition, with its assertion of universal standards and perceptions, has been challenged on many grounds, by sociologists, feminist critics, postmodernists, and artists, among others. One especially useful critique insists on the centrality of the historical and social contexts in which beauty takes form and achieves meaning. That, in turn, requires a consideration of how meanings are ascribed to a wide range of cultural products, and by whom. How do particular societies or social groups define beauty? What categories of taste do they employ? How do they discern the qualities of the beautiful? When is an object "art" and when is it a "tchotchke"? What makes a beauty queen? This approach asks us to consider vernacular aesthetic forms as well as the Old Masters. And it requires us to study

3. For a brief description of the aesthetic tradition, see Peggy Zeglin Brand and Carolyn Korsmeyer, eds., Feminism and Tradition in Aesthetics (University Park, Pa., 1995), 1-22. A foundational text is Immanuel Kant, The Critique of Aesthetic Judgement (1911; Oxford, 1952). On nineteenth-century beauty ideals, see Lois Banner, American Beauty (Chicago, 1984); Karen Halttunen, Confidence Men and Painted Women: A Study of Middle-Class Culture in America, 1830-1870 (New Haven, Conn., 1982). 
viewers' perceptions, their cultural frames of reference, and their social locations, so as not to assume a universal subject. 4

Beauty signifies difference in a number of registers, making distinctions between high and low, normal and abnormal, virtue and vice. In so doing, beauty helps to define morality, social status, class, gender, race, and ethnicity. Ideals of beauty in turn are fundamentally shaped by social relations and institutions, by other cultural categories and practices, and by politics and economics. Even so, beauty should not be reduced to any one of these: if not autonomous, the aesthetic is a realm with its own language and logic. One need not be a sociobiologist tracing contemporary attitudes toward beauty back to our evolutionary heritage and genetic hardwiring to think this. ${ }^{5}$ Rather, one only need recognize that beauty ideals, as well as our perceptions and reactions, develop in complex ways.

Each historical period has its own, culturally specific, standards of beauty: the hourglass figure of the 1890s, the boyish flapper of the 1920s, the unisex look of the 1960s. Yet conceptions of beauty are quite long-lived, their referents going far back in time: in the West, the classical beauty of Greece and Rome remains a governing beauty ideal; many Americans still consider African appearances beautiful only if exoticized. At the same time, beauty is destabilizing because perception, which constructs beauty, occurs in complex individual and cultural circumstances. Beauty turns heads, stops the action, and evokes emotions from lust to piety. Once we have analyzed the social constructions, cultural practices, politics, and economics, we still may not fully understand what beauty does in people's lives and what it means. In its largest sense, aesthetics offers us a way of knowing the world around us in a different key than, say, science or religion. Beauty is, in Suzanne Langer's evocative phrase, "significant form." And it is a form that, in the past century, has been increasingly mobilized and informed by business enterprise. ${ }^{6}$

4. Brand and Korsmeyer, eds., Feminism and Tradition in Aesthetics; George E. Marcus and Fred R. Myers, "The Traffic in Art and Culture: An Introduction," in their anthology, The Traffic in Culture: Refiguring Art and Anthropology (Berkeley, Calif., 1995), 1-51. For an excellent study of vernacular aesthetics, see Judith Goldstein, "The Female Aesthetic Community," in ibid., 310-29.

5. For the sociobiological perspective, see Nancy Etcoff, Survival of the Prettiest: The Science of Beauty (New York, 1999).

6. Suzanne Langer, Feeling and Form: A Theory of Art (New York, 1953). For a feminist psychoanalytical perspective, see Griselda Pollack, "Woman as Sign: Psychoanalytic Readings," Vision and Difference: Femininity, Feminism, and the Histories of Art (London, 1988), 120-54. 


\section{The Beauty Sector of the Economy}

Beauty and business seem most closely related in the modern era, but beauty has always been for sale. Whenever and wherever markets have arisen, beauty has had a commercial value. Art markets developed among elites, whether Renaissance princes, Gilded Age robber barons, or Cold War corporate leaders. As patrons to artists and buyers of beautiful objects, they claimed and projected cultural power. Romanticist ideals of beauty in nature, from the pastoral to the sublime, became the currency of real estate and tourism: a splendid view turned a profit. ${ }^{7}$

Beauty added exchange value to women, whether in the market in slaves, in prostitutes, or in wives. Abolitionist writer and former bondswoman Harriet Jacobs noted how beauty was a misfortune for African women sold as commodities in slavery, since it made them the sexual prey of their masters. Women who bargained their sexual services as prostitutes worked in a hierarchy. Beauty, youth, and fashionability were for sale in "high-class" brothels; women without those attributes toiled in factory-like "cribs" and walked the streets. And as feminists from Mary Wollstonecraft to Emma Goldman charged, marriage was a market in which beauty, not brains, found the highest bidder. It is no coincidence that cosmetics and paints were viewed in the nineteenth century as particularly pernicious symbols of commerce, linked to prostitution, female con artists, and tainted goods. ${ }^{8}$

If beauty ideals and practices were shaped by earlier exchange values, they in turn set limits and created opportunities for the modern fashion and beauty industries. Despite similar emphases on style and

7. On art markets, see Marcus and Myers, eds., Traffic in Culture; Edward Goldberg, After Vasari: History, Art, and Patronage in Late Medici Florence (Princeton, N.J., 1988); Paul DiMaggio, "Cultural Entrepreneurship in Nineteenth-Century Boston: The Creation of an Organizational Base for High Culture in America," Media, Culture and Society 4 (1982): 33-50; Judith A. Barter, "The New Medici: The Rise of Corporate Collecting and Uses of Contemporary Art, 1925-1970” (Ph.D. diss., University of Massachusetts, Amherst, 1991). On tourism, Dona Brown, Inventing New England: Regional Tourism in the Nineteenth Century (Washington, D.C., 1995); Karen Dubinsky, The Second Greatest Disappointment: Honeymooning and Tourism at Niagara Falls (Toronto, Ont., 1999).

8. On beauty and the market in women, see Harriet A. Jacobs, Incidents in the Life of a Slave Girl, ed. Jean Yellin (Cambridge, Mass., 1987), 11; Timothy J. Gilfoyle, City of Eros: New York City, Prostitution, and the Commercialization of Sex, 1720-1920 (New York, 1992); Emma Goldman, "The Traffic in Women” and "Marriage and Love," in The Traffic in Women and Other Essays on Feminism, ed. Alix Shulman (New York, 1971). 
appearance, beauty and fashion actually followed different logics, and the businesses that sold them developed on separate tracks. In distinct ways, entrepreneurs, local firms, national businesses, and mass media projected beauty and fashion as representations, sold them as tangible goods, and promoted them in the name of service to women.

The "fashion system" predated the emergence of a widespread commercial beauty culture. Fashion transforms clothes as material objects through a process of style creation and information dissemination: it requires news about "what's new" to be spread in print, through images, and by word of mouth. The nineteenth-century publishing industry, especially the genteel women's magazine, created and encouraged women readers in part by promoting new styles and taste. Making fashion the centerpiece of its appeal, Godey's Lady's Book contained the latest news from Paris, London, and New York, ran engravings and fashion plates, and offered instructions for updating older clothes with trimmings, embroidery, new sleeves, and other techniques. ${ }^{9}$

In the nineteenth century, genuine beauty was considered different from fashion - a timeless, inner, and natural quality, not mutable, external, or socially driven. Still, magazine and book publishers made advice, illustrations, and fiction about beauty a salable product that helped fuel the publishing boom after 1830. Don't buy cosmetics, went the sales pitch, but do buy the book on how to achieve moral beauty. Godey's and handsome gift books disseminated ideals of appearance to affluent women, while low-cost beauty manuals reached factory hands and domestic workers. Expanded literacy, faster and cheaper printing technologies, and new book distribution systems fostered a market for beauty advice across the socioeconomic spectrum. ${ }^{10}$

What we often call "prescriptive literature"-in contrast to such private writings as letters and diaries - was often, in fact, a product of business and should be examined in that light. In Godey's and the advice manuals, emergent genre conventions, representational strategies, and narrative structures developed to keep women buying and reading. The fashion plates and gossip about Parisian and New

9. On nineteenth-century fashion, see Halttunen, Confidence Men and Painted Women, 56-91; Banner, American Beauty, 17-27, 45-65. On the clothing industry in the United States, see Claudia B. Kidwell and Margaret C. Christman, Suiting Everyone: The Democratization of Clothing in America (Washington, D.C., 1974); on France, Philippe Perrot, Fashioning the Bourgeoisie: A History of Clothing in the Nineteenth Century (Princeton, N.J., 1994). On fashion as a symbolic process, see Roland Barthe, The Fashion System (1967; Berkeley, Calif., 1990); Gilles Lipovetsky, The Empire of Fashion: Dressing Modern Democracy (Princeton, N.J., 1994).

10. Banner, American Beauty, 28-44; Kathy Peiss, Hope in a Jar: The Making of America's Beauty Culture (New York, 1998), 9-36. 
York high society promised the dernier cri to American women in the hinterlands. Magazine fiction gratified readers' interest in good looks while implicitly praising their good sense and good name: short stories featured willful beauties who painted and primped in pursuit of husbands and fortune but died of lead poisoning from toxic face powder or developed consumption after dancing all night in sheer, lowcut ball gowns. ${ }^{11}$

If nineteenth-century beauty ideals tended to naturalize gender differences and legitimate the new cultural authority of the middle class, they also spurred the growth of a women's market in publishing. This early commercial dissemination of feminine ideals and images was critical in the making of mass-market beauty and fashion industries. It began a long-term process of educating the eye, channeling desires, and creating an identification between representation and viewer that would serve the sale of goods and foster new perceptions of beauty in the culture at large.

Just as important was the web of small-scale proprietors, entrepreneurs, manufacturers, and retailers who, by the late nineteenth century, had established fashion and beautifying as cultural practices linked to commerce. Their stories have been especially important to recover, for they complicate our historical understanding of the beauty and fashion sector of the economy and suggest some new directions for business history. Perhaps most significant is the role of women in these businesses: seamstresses, hairdressers, beauticians, department store buyers, and cosmetics saleswomen all made beauty and fashion integral to the lives of women. As Wendy Gamber has shown, dressmakers and milliners were ambitious, independent, and skilled craft workers, who often became proprietors of their own shops, secured a competency, and achieved some standing in their communities. They had to be highly responsive to information about what was stylish, respectable, and attractive, and they became authorities themselves, translating high style and fashion plates for local tastes and pocketbooks. ${ }^{12}$

The beauty business has also been and remains intensely personal. What began as domestic service - the hands-on care of the hair, face, and body by maids or slaves - became organized into businesses by individual proprietors and entrepreneurs in the late nineteenth

11. This discussion of genre conventions is informed by the work of Janice Radway, Reading the Romance: Women, Patriarchy, and Popular Literature (Chapel Hill, N.C., 1984). For an example of this literature, see Caroline Lee Hentz, "The Fatal Cosmetic," Godey's Lady's Book 18 (June 1839): 265-79.

12. Wendy Gamber, The Female Economy: The Millinery and Dressmaking Trades, 1860-1930 (Urbana, Ill., 1997). 
century. These beauty enterprises began to appear in cities across the country: a manicure shop tucked away in a multi-floor walkup, a storefront hair salon, a "beauty college" in a loft, the cosmetics counter front and center in department stores. ${ }^{13}$

These businesses opened opportunities for some women by aligning commercial enterprise with the very ideals of femininity and beauty that had long justified women's exclusion from most lines of work. In a culture that celebrated inner, moral beauty, they placed a new emphasis on external appearance and its cultivation through the purchase and use of cosmetics and other beauty aids. They directed their business and marketing efforts not only to the affluent but to working women, African Americans, and immigrants, drawing on the cultural practices and institutions familiar to women in their everyday life.

The beauty business joined the sale of goods to the provision of services in innovative ways. Avon saleswomen went into homes to teach women about beauty products and how to use them. Unlike selling vacuum cleaners and encyclopedias door to door, selling beauty often involved a long-term, continuous relationship between seller and buyer. Salons were based in specific localities, and their handson approach offered the pleasure of touch, the promise of makeover, and the enjoyment of sociability. Franchising operations and beauty schools spread what began as local, personal endeavors across the country; women went to a Madam C. J. Walker or Marinello shop for a particular experience of hair styling, grooming, and social interaction. In African American salons, the small talk between hairdresser and client sometimes turned to matters of economic and political import and even nourished community activism and the civil rights movement. ${ }^{14}$

Woven into the "house calls" of the Avon Lady and the washand-set at the beauty parlor was an ongoing conversation about appearances that opened out in many directions. These businesses encouraged a high degree of self-consciousness of the face and body. Operating in a local context, they reinforced yet mediated the barrage of advertising, motion pictures, and national magazines that fostered an external, visual standard for self-assessment.

13. The following discussion relies on my book, Hope in a Jar, chap. 3.

14. On Avon, see Katina L. Manko, "Now You Are in Business for Yourself': The Independent Contractors of the California Perfume Company, 1886-1938," Business and Economic History 26 (1997): 5-26. On the politics of African American hair salons, see Tiffany Melissa Gill, “'I Had My Own Business . . . So I Didn’t Have to Worry': Beauty Salons, Beauty Culturists, and the Politics of African American Female Entrepreneurship," in Beauty and Business, ed. Philip Scranton (New York, forthcoming, 2000). 
Selling beauty itself as a product became much more systematic, self-conscious, and widespread after 1920. Historians have only begun to research the full dimensions of this effort across the economy and society - not only in specific cosmetics, haircare, clothing, and accessories firms, but in modeling agencies, commercial beauty contests, cosmetic surgery, weight camps, the health club business, and other enterprises. Scholars have delineated the role of beauty and fashion in furthering the development of national and mass markets. They have written extensively, for instance, on the "tie-in" as an integrative business strategy in cosmetics and fashion marketing by which local retailers, national advertisers, mass-circulation magazines, and movies aligned their interests. Film producers built in moments of female display and spectacle in the movies not only for the male gaze, but also for women viewers - the obligatory "how do I look" scene in front of the mirror or the staging of a fashion show. Movie studios struck agreements with clothing manufacturers to highlight new styles. If a dress received particular notice from fans - like that worn by Bette Davis in Letty Lynton-it was quickly manufactured at popular prices and featured in department stores. ${ }^{15}$

These cooperative strategies and nationalizing tendencies stand in contrast to the ongoing conflicts among local businesses, national media, and mass manufacturers. The local and regional remain salient in the modern beauty and fashion business. Although the rise of ready-to-wear fashions put many dressmakers out of business or turned their activity into alteration work for stores, women with an understanding of clothes often became specialty shop owners or department store buyers. Buyers made and continue to make decisions about New York or Paris fashions based on their understanding of hometown constituencies. Specialty shops have sought the trust of customers through personal service and sensitivity to local standards of beauty and style. ${ }^{16}$ That sensitivity is not just a matter of price but an awareness of taste- what color palette, design elements, and accessories appeal to the eyes of women in their communities, whether middle-class African Americans, Jewish retirees in Florida, or workingclass secretaries in Dallas. Beauty shops also mediate the national and

15. On the systematic sale of style, see William Leach, Land of Desire: Merchants, Power, and the Rise of a New American Culture (New York, 1993); Peiss, Hope in a Jar, 122-33. On tie-ins, see Charles Eckert, "The Carole Lombard in Macy's Window," in Fabrications: Costume and the Female Body, ed. Jane Gaines and Charlotte Herzog (New York, 1990), 100-121; Charlotte Herzog, “'Powder Puff' Promotion: The Fashion Show-in-the-Film," in ibid., 134-59.

16. Sarah Elvins, "Selling Hinterland Style: Fashion Retailing in Upstate New York, 1920-1940,” paper presented at the Hagley Museum and Library Spring Conference on Beauty and Business, 26-27 March 1999, Wilmington, Del. 
the local. Salon operatives promote trends created by product manufacturers, trade associations, and celebrity hair designers while remaining attentive to the particular practices and views of their patrons.

If beauty is a signifier of difference, beauty businesses - whether national, regional, or local-have continually made choices about what differences to emphasize, reinforce, or efface. Hairdressers have long been trained in different techniques that reinforce a racial distinction between "black" and "white" hair. Instructions on permanent waves in the 1930s, for instance, emphasized marcelling for white clients, croquignole waves for African American women. Even after the desegregation of beauty schools and beauty shops in the 1960s, these customary distinctions continued. Hair is most obviously a potent symbol of gender difference. The rise of "unisex" salons and men's hair styling in the 1960s was an important development in the beauty business that challenged the dominance of the barber shop as the bastion of male appearance. Unisex styling salons capitalized upon the larger questioning of traditional notions of masculinity by men in the "youth revolt," counterculture, and antiwar movement of the time.17

These examples suggest how much beauty businesses have shaped the social definitions and physical attributes of femininity and masculinity, as well as race and ethnicity, age and generation, and class. They have done so not only through advertising, but through product design, sales strategies, and in the daily operations and practices that underlie brand and company identity. For instance, in oral history interviews conducted by the Smithsonian Institution, the Noxell (originally Noxzema) corporation and its advertisers were extremely forthcoming about their choices when developing and marketing Cover Girl makeup in the late 1950s and 1960s. Noxzema was already established as a maker of a medicated cleansing and moisturizing cream when it decided to create a makeup line. The product was, in its initial development, intended for both young adult women and teenagers with "problem" skin, and the challenge was to make the product acceptable to both groups, as well as to parents of teens anxious about their daughters' use of makeup. Mary Ayres, an advertising executive handling the account, developed the idea of Cover Girl as a medicated makeup, with the advertising stressing both glamour and health. Among the early slogans were "glamour that's good for your skin" and "clean makeup."18

17. Julie A. Willett, Permanent Waves: The Making of the American Beauty Shop (New York, 2000); Susanna Walker, "Black Is Profitable: The Commodification of the Afro, 1960-1975," in this issue.

18. Peiss, Hope in a Jar, 262-63; Cover Girl Make-Up Advertising Collection, 1959-1990, Archives Center, National Museum of American History, Smithsonian 
By the mid-1960s, the agency had consciously decided upon a particular vision of female beauty to sell this idea: a young, fair-skinned, sun-bleached blonde, fit and active, yet absorbed in her own beauty. Modeled by Cybill Shepherd and Cheryl Tiegs, this "California look" was specifically intended to appeal to Middle America, the mass market and cultural mainstream. The ad designers perceived the light skin of models and white space in the ads as a "clean" look, and "cleanliness" was a message that they believed would appeal to girls and parents alike. The manufacturer had its own concerns, including keeping the price of the product competitive, simplifying packaging, gaining shelf space in drugstores, and managing consumers' choices in a self-service environment; for all these reasons, the firm created at first only three, then seven shades of foundation, none of them appropriate for deep olive, brown, or black complexions. This example illustrates how a mass-market company, through a complex process of decision making and a deeply engrained set of cultural biases, can produce and reproduce racialized and gendered beauty ideals.

\section{Aestheticization as a Business Strategy}

The perception that "beauty sells" became commonplace in business after 1920. Scholars have studied how manufacturers and advertisers have long used representations of beautiful women and handsome men both to sell specific products and to promote consumption-oriented lifestyles. The "beauty appeal" as a self-conscious commercial strategy went further, by promising consumers the psychological and social benefits of better looks. The beauty appeal moved well beyond the cosmetics and fashion industries and was used to sell virtually any product that could be connected in some way to the body, selfpresentation, and personal identity. Toothbrushes made by the Prophylactic Brush Company, once sold on the basis of health and hygiene, were now guaranteed to beautify one's smile; Wrigley touted chewing gum as a five-minute facial for secretaries; automobile advertisements encouraged women to buy cars to match their frocks. Articles on "beauty, the new business tool" appeared throughout trade journals, in-house newsletters, and the popular press. ${ }^{19}$

To many manufacturers, beauty was a measurable value added to goods, a quantum that could alter the perception and placement of

Institution, Washington, D.C.; see especially interviews with L. C. "Bates” Hall, George Poris, Malcolm MacDougall, and Peter Troup.

19. Ernest Elmo Calkins, “Beauty, the New Business Tool,” Atlantic, Aug. 1927. 
products. Lever Brothers, maker of a popular laundry detergent, stressed the value of glamour when it introduced Lux toilet soap in 1925. It hired the J. Walter Thompson Company to develop a marketing and advertising campaign. When Thompson offered its proposal for ads that promoted Lux as a "new form" of soap, Lever's president complained that the ads would confuse consumers into thinking that the soap was simply another kind of laundry detergent. "Our idea," he said, is that the toilet soap "should be placed on a pinnacle, removed from any suggestion of laundry or dishpan use." He urged the advertising agency to replace the word "suds" with "lather" and to depict the soap in the boudoir, not in the kitchen. "We must throw more glamour around our new product to justify the price in the consumer's mind of 9c to 10c per cake. . . . Remember, we are lifting a laundry product up to a toilet plane."20

Aesthetic categories helped businesses define and build their markets. Cosmetics manufacturers relied heavily on package design and targeted advertising to reach particular consumers. African American businessman Anthony Overton wanted the packaging of High-Brown Face Powder to be elegant and respectable, and he chose the face of a woman with light brown skin and European features to adorn the label. The French perfumer Bourjois sold Java face powder in a traditional loose-powder container with a floral design, touting it as a "natural" beauty aid for conservative, older women who balked at looking made up; Bourjois placed the same powder in a jazzier package, named it Manon Lescault, and marketed it to flappers as a tool for manhunting and romance. Businesses that used aesthetic codes to convey social and moral messages would find that "it is quite possible to reach two mutually antagonistic classes of prospects," one trade journal observed. ${ }^{21}$

Businesses worked with older aesthetic categories, updated and shaped them for commercial purposes, and made them relevant to the perceptions and tastes of consumers. Sales campaigns used typologies of beauty - dark and fair, foreign and exotic, ethereal and physical — to differentiate products and markets. Max Factor and other cosmetics firms created complexion analysis charts to help women choose their "beauty type" and the best array of products. Earlier aesthetic dictates appear repeatedly in advertising. William Hogarth's "curve of beauty"- a sinuous "S" shape identified by the eighteenth-century

20. J. A. Countway to Stanley Resor, 27 January 1925, Client Files, Lever Brothers, Sidney Bernstein Papers, J. Walter Thompson Advertising Collection, Duke University, Durham, N.C.

21. Roy W. Johnson, "Copy Strategy Sells Face Powder to Flappers and AntiFlappers,” Printers’ Ink 120 (28 Sept. 1922): 89; Peiss, Hope in a Jar, 215. 
writer as the most beautiful line-inspired an advertisement for Zip depilatory: the model's pose, one arm curved above her head to reveal a hairless underarm, rendered the otherwise indelicate subject artistic and tasteful. 22

Business leaders also adopted new artistic movements that they perceived as having commercial value. The forward-looking aesthetic of art moderne was attached to many products with varying degrees of success. Everything from trains to toasters was streamlined to convey a sense of speed and modernity. The beauty firm Marinello even packed face cream in jars that looked like set-back skyscrapers. Retailers looked to artists and museums for aesthetic inspiration and design trends for store layout, show windows, and special events. Advertisers too used new artistic elements to position their products in the marketplace - for example, hiring leading photographer Edward Steichen to take modernist shots of hands for Jergens Lotion. Coordinated designs and ensembles, inspired by clothing fashion, could be seen in products ranging from cosmetics to furniture to bathroom fixtures. Today this principle informs the lifestyle marketing of such stores as Pottery Barn and Rooms to Go. ${ }^{23}$

Beyond marketing and sales, beauty and appearance have played an important role in employment, conveying through the body a set of messages about a firm. Formal uniforms, customary dress codes, hair styles, makeup requirements, and weight restrictions became visual cues that served to unify the corporate or brand identity, put forward a pleasing face to the public, and manage employees. This has been especially true in white-collar and service-sector jobs, in which people are, in a sense, part of the company's product. After World War II, when airlines chose women over men to work as flight attendants, rules stipulating appropriate appearance became commonplace. By the 1960s flight attendants were required to wear nail polish, lipstick, hats, gloves, and girdles; hair coloring, Afros, and cornrows were banned. Limitations on body weight had nothing to do with overloading the plane and everything to do with projecting an image of svelte, youthful beauty. National Airlines' infamous "Fly Me” advertising campaign of the 1960s sold the vicarious experience of flight attendants' sexuality and beauty along with air transportation.

22. See William Hogarth, The Analysis of Beauty, ed. Ronald Paulson (New Haven, Conn., 1997); Zip depilatory pamphlet, n.d., in author's possession.

23. Jeffrey Meikle, Twentieth Century Limited: Industrial Design in America, 1925-1939 (Philadelphia, Pa., 1979); Leach, Land of Desire. On the business and cultural problems packaging and design posed for manufacturers, see Glenn Porter, "Cultural Forces and Commercial Constraints: Designing Packaging in the TwentiethCentury United States,” Journal of Design History 12 (1999): 25-45. 
Such requirements have increasingly become the source of individual and collective conflict in the workplace. In the 1970s, the flight attendants' union successfully fought both marital status and weight requirements as discriminatory; both requirements constructed "the stewardess" as youthful and attractive. African American women have challenged employers who bar corn rows, dreadlocks, and other hair styles from the workplace: designating an appropriate corporate identity, they argue, has the effect of enforcing a "white" appearance. Even more widespread are the gender-, class-, and race-based assumptions about appropriate looks at different levels and kinds of business. These differences were evocatively captured in the 1988 film Working Girl, in which makeup, hair, and clothing styles distinguished the women managers from the secretaries. As Melanie Griffith's upwardly mobile and newly shorn character explains, "If you want to be taken seriously, you need to have serious hair."24

Aestheticization has also proven to be a powerful business strategy in establishing corporate identity. Since the 1930s, but especially after World War II, corporations have projected their economic and political power through a "corporate aesthetic." Henry Luce intentionally made Fortune, a general magazine for businessmen, into a beautiful physical object at the very moment - the onset of the Depression - when many publishers were cutting the quality of paper and illustrations and shrinking the size of magazines. Despite the high cost, Luce printed Fortune in large format and on heavy paper stock, hired modernist artists to design the covers, and commissioned renowned photographers to take the pictures that appeared inside the magazine. ${ }^{25}$

Individual and corporate ownership of art collections also became an important means of projecting cultural and economic authority. Helena Rubinstein had an extensive art collection, which she showed in her New York salon and loaned to museums; it underscored Rubinstein's belief that beautifying was not a practice of the vulgar and

24. Georgia Panter Nielsen, From Sky Girl to Flight Attendant: Women and the Making of a Union (Ithaca, N.Y., 1982), 10, 98-101; see also Dorothy Sue Cobble, Dishing It Out: Waitresses and Their Unions in the Twentieth Century (Urbana, Ill., 1991). On African American women and discrimination cases based on appearance, see Paulette M. Caldwell, "A Hair Piece: Perspectives on the Intersection of Race and Gender," Duke Law Journal (April 1991): 365-96. Griffith quote from Working Girl (Mike Nichols, director; Twentieth Century Fox, 1988).

25. Kevin Reilly, "Corporate Stories: Fortune Magazine and the Making of Managerial Culture” (Ph.D. diss., University of Massachusetts, Amherst, in progress). On the connections between the post-World War II economy, politics, and aesthetics, see T. J. Jackson Lears, "A Matter of Taste: Corporate Cultural Hegemony in a MassConsumption Society," in Recasting America: Culture and Politics in the Age of Cold War, ed. Lary May (Chicago, 1989), 38-57. 
vain but a "decorative art," part of a celebrated aesthetic tradition. Some business leaders, like Walter Paepcke, the head of the Container Corporation of America, patronized abstract artists as representatives of free enterprise and the free world. More generally, arts patronage, public sculpture, and commissions to renowned architects have been used in corporate, white-collar settings to project a sense of common mission and elevated status: the "corporate sublime." 26

\section{Beauty from High to Low}

Business may promote the "corporate sublime" to express its higher aims, but it has also used beauty for "lower" purposes. The exploitation and sale of sexualized beauty and its larger impact on the economy and society remain largely unexamined by business historians. Yet "smut peddling”- as Hustler owner Larry Flynt quaintly calls it, evoking a by-gone era of shrewd, sweet-talking men carrying packs full of trinkets - is in fact big business. Changing beauty ideals and images affected the contours and growth of this industry, including its movement from illicit trade to legitimate enterprise.

The modern invention of pornography has been linked to the development of printing and consequent distribution of books, magazines, pamphlets, and ephemeral literature, a development associated, interestingly, with the emergence of a Habermasian "civic" public sphere in the eighteenth century. ${ }^{27}$ Beauty became more important to smut peddling as new image-making technologies developed. By the 1860 s, the unique image of the daguerreotype gave way to carte-devisites, stereographs, and other reproducible formats. A lively trade resulted, not only in the manufacture of personal portraits, but also in the sale of the pictures. Photography studios, peddlers, and mailorder firms marketed the faces and figures of actresses, dancers, burlesque performers, self-styled beauties — and naked women. Pho-

26. For an excellent discussion, see Neil Harris, "Designs on Demand: Art and the Modern Corporation," in Cultural Excursions: Marketing Appetites and Cultural Tastes in Modern America (Chicago, 1990), 349-78. See also Parke-Bernet Galleries, Modern Drawings and Watercolors: The Collection of Helena Rubinstein (New York, 1966); Barter, “The New Medici”; Serge Guilbaut, How New York Stole the Idea of Modern Art: Abstract Expressionism, Freedom, and the Cold War (Chicago, 1983).

27. On the history of pornography, see Lynn Hunt, ed., The Invention of Pornography: Obscenity and the Origins of Modernity, 1500-1800 (New York, 1993); Walter Kendrick, The Secret Museum: Pornography in Modern Culture (New York, 1987); Linda Williams, Hard Core: Power, Pleasure and the "Frenzy of the Visible" (Berkeley, Calif., 1989). 
tographers embraced specific styles of posing, camera placement, and lighting that regularized images of beauty, including those intended to be sexually arousing. And they drew upon conventions of display and spectacle developed first in burlesque and musical reviews and later in body building and beauty pageantry. Images of beauty used to sell products explicitly to men, especially those connoting a male "sporting" culture, emphasized female physical attributes. Bosomy, dark-featured women regularly appeared on cigar boxes, for instance. ${ }^{28}$

It is striking indeed how frequently businesses that are based on new, image-making technologies use sex and sexualized beauty to gain a foothold in the entertainment and information economy. In the early days of motion pictures, most films were projected on screens in vaudeville shows, nickelodeons, and traveling exhibitions, but dime museums and "peep shows" featured kinescopes of women flirting and disrobing. Radio and television were tightly regulated for sexual content, but the largely unregulated areas of videocassette production and Internet commerce have depended heavily on sex as a source of profit. Blockbuster and other video outlets have, in fact, seriously undermined the older forms of sexual entertainment in vice districts - the peep shows and triple X theaters; what had once been largely a male viewing habit and male-defined product has changed dramatically with the striking numbers of women renting X-rated videos. In the early years of Internet commerce, high-tech smut peddlers have profited the most in this new medium of communication and entertainment. ${ }^{29}$

Until the mid-1970s, pornography had been an illicit enterprise, and its history is still largely uncharted. These businesses were run by entrepreneurs who did not want their activities documented. What we do know comes largely from the traces of smut peddlers, low-life printers, nude-model photographers, and others appearing in trial records and government-led crackdowns. The legal repression of obscenity, such as the Comstock Act, was fundamentally a restraint on trade, and pornographers fought to preserve their businesses, not just their free speech rights. Occasionally these firms did leave records, and one, at least, suggests the complex network of under- and above-

28. On photography, Abigail Solomon-Godeau, "The Legs of the Countess," October 39 (Winter 1986). On sexualized women, display, and spectacle, see Robert Allen, Horrible Prettiness: Burlesque and American Culture (Chapel Hill, N.C., 1991); Banner, American Beauty, 120-27.

29. Charles Musser, The Emergence of Cinema: The American Screen to 1907 (New York, 1990); Jonathan Coopersmith, "Pornography, Technology, and Progress," Icon 4 (1998): 94-125; Nick Ravo, “A Fact of Life: Sex-Video Rentals,” New York Times, 16 May 1990, C-1. 
ground transactions. H. Lynn Womack, a mail-order publisher of gay pornography, had contacts in photography studios, in the armed forces, and in the gay community, who sent him snapshots and portraits of young men, either fully clothed or in briefs or bathing suits. From these he selected the images that best fit the appearance requirements of his publications - and he commented on them - the body builder, a winsome "chicken," a "well hung" model. ${ }^{30}$ In this way, Womack actively constructed masculine beauty directed to the gay male market.

Since the 1950s, ideals of beauty have helped the pornography business redefine the line between licit and illicit, between "smut" and "adult entertainment." Playboy pioneered the way by calling itself a "men's magazine," with fiction, advice columns, and interviews, as well as naked women. The Playmate blurred the boundary between sex queen and girl next door. The magazine's photographers drew upon pictorial conventions from fashion photography and "pinup" posing. Airbrushing, makeup, and lighting perfected the beauty of the female image; layout further domesticated the sexualized image by juxtaposing the Playmate's naked body, personal biography, "everyday" snapshots, and portrait. The magazine's imagery was more similar to the style of the Miss America beauty pageant than to underground X-rated photographs. As courts chipped away at the obscenity standard and many Americans embraced the "sexual revolution," the adult entertainment industry was born. This industry used familiar business strategies of legitimation: it started trade journals and associations, rationalized distribution and marketing, used genre narratives and visual conventions, and differentiated beauty ideals to appeal to different consumer tastes. ${ }^{31}$

\section{Beauty and Business}

Beauty, fashion, and style are threaded through the history of American business - as a product for sale, as a system of representations, and as a category of taste and discrimination. The implications of beauty in business are complex and contradictory: beauty images simultane-

30. See H. Lynn Womack Papers, Human Sexuality Collection, Division of Rare and Manuscript Collections, Kroch Library, Cornell University, Ithaca, N.Y.

31. On Playboy, see Barbara Ehrenreich, The Hearts of Men (Garden City, N.Y., 1983); Joanne Meyerowitz, "Women, Cheesecake, and Borderline Material: Responses to Girlie Pictures in the Mid-Twentieth-Century U.S.," Journal of Women's History 8 (1996): 9-35. On Esquire's early effort to define male consumers in part through aesthetic categories, see Kenon Breazeale, "In Spite of Women: Esquire Magazine and the Construction of the Male Consumer," Signs 20 (1994): 1-22. 
ously promise and withhold, elevate and degrade. They are sanitized and sexualized, aspirational and arousing. Beauty has advanced modern business at many levels. It represents and projects corporate identities. It has opened entrepreneurial opportunities for women, even as it fosters the exploitation of women's bodies. Indeed, it has ignited the commercial potential of information and entertainment businesses.

Nor is this only an American story: the face of global capitalism is not so much streaked with sweat as it is carefully "made-up." The fall of the Soviet Union, for example, led to the resurgence of commercial beauty culture among Russian women, many of whom embraced a self-consciously feminine beauty image that departed from the Communist ideal. In China, India, and even Amazon rainforests, women sell Avon, Mary Kay, and other beauty products; as was the case one hundred years ago in the United States, these "micro-businesses" have given some women a foothold in the developing market economy. ${ }^{32}$ Selling, marketing, and projecting beauty have only become more important to the workings of a global, media-oriented economy. Commerce, in turn, links goods, looks, status, and identity to influence how cultures define the norms of appearance for women and men. Beauty and business may seem to exist in different domains but, as the new scholarship shows, their relationship grows ever closer and more significant.

32. On global beauty culture, see Colleen Ballerino Cohen, Richard Wilke, and Beverly Stoeltje, eds., Beauty Queens on the Global Stage: Gender, Contests, and Power (New York, 1996); Sarah Banet-Weiser, The Most Beautiful Girl in the World: Beauty Pageants and National Identity (Berkeley, Calif., 1999). On the global sale of cosmetics, see Gabrielle Glaser, "In Poland, Studying the Fine Art of Chic," New York Times, 11 Sept. 1991, C-9; Nicholas Kristof, "Let a Thousand Lipsticks Bloom,” ibid., 3 May 1992, section 9, p. 2; Ron Harris, "Avon Ladies Find Success in Jungles of Brazil," Springfield Union-News, 6 Sept. 1994; Alessandra Stanley, "New Face of Russian Capitalism; Avon and Mary Kay Create New Opportunities for Women," New York Times, 14 Aug. 1996, D-1.

\section{Bibliography of Works Cited}

Books

Allen, Robert. Horrible Prettiness: Burlesque and American Culture. Chapel Hill, N.C., 1991.

Banet-Weiser, Sarah. The Most Beautiful Girl in the World: Beauty Pageants and National Identity. Berkeley, Calif., 1999.

Banner, Lois. American Beauty. Chicago, 1984.

Barthe, Roland. The Fashion System. 1967; Berkeley, Calif., 1990.

Bordo, Susan. Unbearable Weight: Feminism, Western Culture, and the Body. Berkeley, Calif., 1993. 
Brand, Peggy Zeglin, and Carolyn Korsmeyer, eds. Feminism and Tradition in Aesthetics. University Park, Pa., 1995.

Brown, Dona. Inventing New England: Regional Tourism in the Nineteenth Century. Washington, D.C., 1995.

Cobble, Dorothy Sue. Dishing It Out: Waitresses and Their Unions in the Twentieth Century. Urbana, Ill., 1991.

Cohen, Colleen Ballerino, Richard Wilke, and Beverly Stoeltje, eds. Beauty Queens on the Global Stage: Gender, Contests, and Power. New York, 1996.

Dubinsky, Karen. The Second Greatest Disappointment: Honeymooning and Tourism at Niagara Falls. Toronto, Ont., 1999.

Ehrenreich, Barbara. The Hearts of Men. Garden City, N.Y., 1983.

Etcoff, Nancy. Survival of the Prettiest: The Science of Beauty. New York, 1999.

Gamber, Wendy. The Female Economy: The Millinery and Dressmaking Trades, 1860-1930. Urbana, Ill., 1997.

Gilfoyle, Timothy J. City of Eros: New York City, Prostitution, and the Commercialization of Sex, 1720-1920. New York, 1992.

Goldberg, Edward. After Vasari: History, Art, and Patronage in Late Medici Florence. Princeton, N.J., 1988.

Goldman, Emma. The Traffic in Women and Other Essays on Feminism, ed. Alix Shulman. New York, 1971.

Guilbaut, Serge. How New York Stole the Idea of Modern Art: Abstract Expressionism, Freedom, and the Cold War. Chicago, 1983.

Halttunen, Karen. Confidence Men and Painted Women: A Study of MiddleClass Culture in America, 1830-1870. New Haven, Conn., 1982.

Hogarth, William. The Analysis of Beauty, ed. Ronald Paulson. New Haven, Conn., 1997.

Hunt, Lynn, ed. The Invention of Pornography: Obscenity and the Origins of Modernity, 1500-1800. New York, 1993.

Jacobs, Harriet A. Incidents in the Life of a Slave Girl, ed. Jean Yellin. Cambridge, Mass., 1987.

Kant, Immanuel. The Critique of Aesthetic Judgement. 1911; Oxford, 1952.

Kendrick, Walter. The Secret Museum: Pornography in Modern Culture. New York, 1987.

Kidwell, Claudia B., and Margaret C. Christman. Suiting Everyone: The Democratization of Clothing in America. Washington, D.C., 1974.

Langer, Suzanne. Feeling and Form: A Theory of Art. New York, 1953.

Leach, William. Land of Desire: Merchants, Power, and the Rise of a New American Culture. New York, 1993.

Lipovetsky, Gilles. The Empire of Fashion: Dressing Modern Democracy. Princeton, N.J., 1994.

Marcus, George E., and Fred R. Myers, eds. The Traffic in Culture: Refiguring Art and Anthropology. Berkeley, Calif., 1995.

Meikle, Jeffrey. Twentieth Century Limited: Industrial Design in America, 1925-1939. Philadelphia, Pa., 1979. 
Musser, Charles. The Emergence of Cinema: The American Screen to 1907. New York, 1990.

Nielsen, Georgia Panter. From Sky Girl to Flight Attendant: Women and the Making of a Union. Ithaca, N.Y., 1982.

Parke-Bernet Galleries. Modern Drawings and Watercolors: The Collection of Helena Rubinstein. New York, 1966.

Peiss, Kathy. Hope in a Jar: The Making of America's Beauty Culture. New York, 1998.

Perrot, Philippe. Fashioning the Bourgeoisie: A History of Clothing in the Nineteenth Century. Princeton, N.J., 1994.

Radway, Janice. Reading the Romance: Women, Patriarchy, and Popular Literature. Chapel Hill, N.C., 1984.

Willett, Julie A. Permanent Waves: The Making of the American Beauty Shop. New York, 2000.

Williams, Linda. Hard Core: Power, Pleasure, and the "Frenzy of the Visible.” Berkeley, Calif., 1989.

Wolf, Naomi. The Beauty Myth. New York, 1991.

Articles and Essays

Breazeale, Kenon. "In Spite of Women: Esquire Magazine and the Construction of the Male Consumer." Signs 20 (1994): 1-22.

Caldwell, Paulette M. "A Hair Piece: Perspectives on the Intersection of Race and Gender." Duke Law Journal (April 1991): 365-96.

Coopersmith, Jonathan. "Pornography, Technology, and Progress.” Icon 4 (1998): 94-125.

DiMaggio, Paul. "Cultural Entrepreneurship in Nineteenth-Century Boston: The Creation of an Organizational Base for High Culture in America." Media, Culture and Society 4 (1982): 33-50.

Eckert, Charles, "The Carole Lombard in Macy's Window." In Fabrications: Costume and the Female Body, ed. Jane Gaines and Charlotte Herzog. New York, 1990, pp. 100-121.

"The Future of Business History" special issue. Business and Economic History 26 (Fall 1997).

"Gender and Business History" symposium. Business History Review 72 (Summer 1998): 185-249.

Gill, Tiffany Melissa. “'I Had My Own Business . . . So I Didn’t Have to Worry': Beauty Salons, Beauty Culturists, and the Politics of African American Female Entrepreneurship." In Beauty and Business, ed. Philip Scranton. New York, forthcoming, 2000.

Goldstein, Judith. "The Female Aesthetic Community." In The Traffic in Culture: Refiguring Art and Anthropology, ed. George E. Marcus and Fred R. Myers. Berkeley, Calif., 1995, pp. 310-29.

Harris, Neil. "Designs on Demand: Art and the Modern Corporation.” In Cultural Excursions: Marketing Appetites and Cultural Tastes in Modern America. Chicago, 1990, pp. 349-78.

Herzog, Charlotte. "Powder Puff Promotion: The Fashion Show-in-the- 
Film.” In Fabrications: Costume and the Female Body, ed. Jane Gaines and Charlotte Herzog. New York, 1990, pp. 134-59.

Lears, T. J. Jackson. "A Matter of Taste: Corporate Cultural Hegemony in a Mass-Consumption Society." In Recasting America: Culture and Politics in the Age of Cold War, ed. Lary May. Chicago, 1989, pp. $38-57$.

Lipartito, Kenneth. "Culture and the Practice of Business History." Business and Economic History 24 (Winter 1995): 1-41.

MacCannell, Dean, and Juliet Flower MacCannell. "The Beauty System.” In The Ideology of Conduct, ed. Nancy Armstrong and Leonard Tennenhouse. New York, 1987, pp. 206-38.

Manko, Katina L. “'Now You Are in Business for Yourself': The Independent Contractors of the California Perfume Company, 1886-1938." Business and Economic History 26 (1997): 5-26.

Meyerowitz, Joanne. "Women, Cheesecake, and Borderline Material: Responses to Girlie Pictures in the Mid-Twentieth Century U.S.” Journal of Women's History 8 (1996): 9-35.

Pollack, Griselda. "Woman as Sign, Psychoanalytic Readings.” In Vision and Difference: Femininity, Feminism, and the Histories of Art. London, 1988, pp. 120-54.

Porter, Glenn. "Cultural Forces and Commercial Constraints: Designing Packaging in the Twentieth-Century United States.” Journal of Design History 12 (1999): 25-45.

Solomon-Godeau, Abigail. "The Legs of the Countess.” October 39 (Winter 1986).

Walker, Susannah. "Black Is Profitable: The Commodification of the Afro, 1960-1975.” Enterprise \& Society 1 (Sept. 2000): 536-64.

Magazines and Newspapers

Atlantic. Aug. 1927.

Godey's Lady's Book. June 1839.

New York Times. May 1990, Sept. 1991, May 1992, Aug. 1996.

Printers' Ink. Sept. 1922.

Springfield Union-News. Sept. 1994.

Unpublished Sources

Barter, Judith A. "The New Medici: The Rise of Corporate Collecting and Uses of Contemporary Art, 1925-1970.” Ph.D. diss., University of Massachusetts, Amherst, 1991.

Cover Girl Make-Up Advertising Collection, 1959-1990. Archives Center, National Museum of American History, Smithsonian Institution, Washington, D.C.

Elvins, Sarah. "Selling Hinterland Style: Fashion Retailing in Upstate New York, 1920-1940.” Paper presented at the Hagley Spring Conference on Beauty and Business, 26 March 1999, Wilmington, Del.

Reilly, Kevin. "Corporate Stories: Fortune Magazine and the Making of 
Managerial Culture.” Ph. D. diss. University of Massachusetts, Amherst, in progress.

J. Walter Thompson Advertising Collection. Hartman Center for Advertising History, Duke University, Durham, N.C.

H. Lynn Womack Papers. Human Sexuality Collection, Division of Rare and Manuscript Collections, Kroch Library, Cornell University, Ithaca, N.Y.

Media Sources

Working Girl. Mike Nichols, director. Twentieth Century Fox, 1988. 